\title{
ARTICLES \\ Teacher Voice: how is it shaped?
}

Claudia Yolanda Becerra Camargo

\begin{abstract}
This article aims at being an invitation for the readers to reflect upon the way in which our voices as teachers are shaped. My own reflective process geared me towards the characterization of three key issues which -from my personal and professional experience- shape teacher voice. They are: the political relations of power, the curricular choices we make and their implications, and the government policies.

Grounded on some Critical Pedagogy scholars, I define first, Critical pedagogy from my personal stand. Second, I present the definition of teacher voice, from different perspectives, including mine. Third, I describe and illustrate each of the three central features that may shape our voices as teachers and finally, I state some conclusions and pedagogical implications.
\end{abstract}

Key words: Reflective Teaching, Critical Pedagogy, Teacher Voice, Power Relationships at school.

\section{Resumen}

Este artículo pretende ser una invitación a los lectores para que reflexionen acerca de la forma en que nuestras voces como profesor@s son formadas. Mi propio proceso de reflexión me orientó hacia la caracterización de asuntos claves que- desde mi experiencia personal y profesional- forman la voz del profesor (a). Ellos son: las relaciones políticas de poder, las elecciones curriculares que hacemos y sus implicaciones, y las políticas gubernamentales.

Basada en algunos teóricos de la Pedagogía Crítica, defino primero Pedagogía Crítica desde mi posición personal. Segundo, presento la definición de la voz del profesor (a) desde diferentes perspectivas, incluida la mía. Tercero, describo e ilustro cada uno de los tres rasgos centrales que pueden formar nuestra voz como profesor@s y finalmente, establezco algunas conclusiones e implicaciones pedagógicas.

Palabras claves: Enseñanza Reflexiva, Pedagogía Crítica, Voz del Profesor(a), Relaciones de Poder en la Escuela.

* Received: 31-03-05 / Accepted: 30-07-05 


\section{Teacher voice: How is it Shaped?}

To be voiceless is to be powerless.

Cummins (1989)

The present reflection aims at illustrating, under a critical perspective, some features that constitute teacher voice. . I decided to address the concept of teacher voice because I consider that our practices and our discourses as educators define who we are, what we believe in and also what we teach, how we teach and the reasons we do it the way we do. As a result, the reflective process we as teachers may make about this issue might illuminate our actions at school in a more informed and critical manner.

Therefore, it is vital to define the concept of critical pedagogy and teacher voice. In addition, I will present some concepts which I consider important in shaping teacher voice. They are the political relations of power, the curriculum choices we make, and their implications, and the way the government policies also constitute our voices. At the end, I will state some conclusions, and I will provide some pedagogical implications which shed light on the ways we may transform our voice in our settings.

\section{Defining Critical Pedagogy}

The purpose of this first part is to establish the point of departure for my reflection. To begin with, Joan Wink in her book Critical Pedagogy (2000) presents some key aspects which must be considered when defining Critical Pedagogy (henceforth, CP). However, she does a quite relevant consideration: she is not going to state a definition to be memorized. She invites the readers to "move together through these pages until you create a definition that matters to you" (p. 28). Being so, I am going to point out some authors' reflections around the term and finally, I will state my own definition.

First of all, Giroux (1999) concentrates his conception on the way in which schools should rescue students' "lived experiences" in order to represent their communities' beliefs and needs. In words of the author, "Critical Pedagogy argues that school practices need to be informed by a public philosophy that addresses how to construct ideological and institutional conditions in which the lived experience of empowerment for the vast majority of students become the defining features of schooling." 
Moreover, McLaren (2002) grounds his definition of CP on the needs and problems students deal with constantly. Besides, he found that this conception offers two courses of action. "On the one hand, a pedagogy based on student experience encourages us to analyze the dominant forms of knowledge that shape student experiences" and "on the other hand, it attempts to provide students with the means to examine their own particular experiences and subordinate knowledge forms" (p. 242).

In the same way, Wink (2000) establishes a definition of what CP is in her words, for those who really need a definition to be stated. She concludes:

Critical Pedagogy forces us to see the broad social, historical, cultural, and political context of teaching and learning. Critical Pedagogy gives us the courage to say what we see. Critical Pedagogy is grounded in justice, equity, and moral mandates. Critical Pedagogy makes us ask fundamental questions: What is the right thing to do today in my teaching and learning in this particular context? It is as broad as the world and as deep as our own individual lives. Critical Pedagogy makes us look at the world, and it makes us look at our individual role in the world, the community, the classroom. Critical Pedagogy is like a lens that enables us to see more clearly, more critically, more keenly. (p. 44)

To wrap up, I would like to share with you my own definition of CP, which has been constructed after reading different authors. From 'my voice', CP considers the interaction between students and teacher, their contradictions, and complexities. CP implies action and transformation. It takes into consideration factors such as culture, background, experience, and beliefs. Being so, the teaching learning process becomes contextualized. Finally, CP considers critical issues such as equity, justice, democracy, courage, power, and language.

\section{Defining Teacher Voice}

This second concept is quite relevant, because the definition mentioned before points out that CP is based on teachers and students' interactions. Interaction implies communication, and communication at times, consists of voices. Thus, it is necessary to illuminate what is understood by voice in $\mathrm{CP}$, and especially what teacher voice is. 


\section{Voice}

Firstly, Pennycook (2001) defines voice under the context of CP as :

Far more than just speaking; rather, it is a broader understanding of developing the possibilities to articulate alternative realities. And since it has to do with gaining the agency to express one's life, it is less about the medium of voice (speaking, writing, etc) and more about finding possibilities of articulation. (p. 130)

Under this perspective, teachers and students' voices should be articulated in the classrooms. They should be both heard in order to understand the 'other', and his/her conceptions.

Afterwards, Wink (2000) relates voice to courage, and she points out the importance of hearing those voices which most of the times are not heard. To illustrate, she introduces an example given by a preservice teacher called Sheila: "the majority of teachers are women, but their voices are just whispers" (p. 70). Then, in Wink's words, "voice is the use of language to paint a picture of one's reality, one's experience, one's world" ('p. 70).

Besides, McLaren (2002) defines voice as "the cultural grammar and background knowledge that individuals use to interpret and articulate experience" (p. 245). For him, there are a lot of aspects which constitute voice: culture, history, symbols, narratives, and social practices (p. 245). That is why he asserts teachers must be aware of these entire phenomena in order to get a better picture of the reality their students face.

\section{Teacher Voice}

Up to now, two basic concepts have been defined: CP, and voice, as one key aspect in the interaction between students and teachers. Next, the definition of teacher voice will be introduced to explain later some of its components.

For McLaren (2002) teacher voice "reflects the values, ideologies, and structuring principles that teachers use to understand and mediate the histories, cultures, and subjectivities of their students" (p. 246). Wink Claims that our voices express who we are, what we believe in, and what we have lived and experienced. 
Furthermore, he illustrates two kinds of power teacher voice may handle: the oppressive one, in which teacher's values and beliefs subordinates students' "experiences and beliefs" (p. 246). Conversely, the emancipatory power "is experienced when a students' voice is allowed to assert itself so as to be both confirmed and analyzed, in terms of the particular values and ideologies it represents" (p. 246). Moreover, McLaren (2002) states the way in which teacher voice can silence student voice. He considers that there are more internal and external voices which introduce new discourses to teacher voice.

\section{Those Other Voices}

As it was mentioned before, teacher voice not only represents the kind of ideologies and beliefs we have, but how it is shaped by other factors, other internal and external voices. I believe that we consciously or unconsciously, are transmitters of internal and external socio cultural realities and sometimes do not perceive in our discourse. For this purpose, I plan to describe some of those voices below:

\section{The Voice of Political Relations of Power}

Before introducing the political relations of power which are presented in teacher voice, I would like to emphasize that overall, schools are social settings with real problems, real concerns, and real relations of power, too. Reganding liberating education, Paulo Freire (1987) states that "the school system was created by political forces whose centre of power is at a distance from the classroom" (p. 33). In other words, the places where we usually teach are marked and divided in different hierarchies which reflect the way in which society and power are distributed.

Moreover, Pennycook (2001) stresses on how classrooms are micro settings in which relations of power can be clearly found. For him, "the political relations in the world outside are reproduced within the classroom" (p. 115). He also exemplifies his point of view with the ideas stated by Auerbach (1995, cited by Pennycook, 2001):

(. . . .) We are forced to ask questions about the most natural-seeming practices: where is the class located? Where does the teacher stand or sit? Who asks questions? What kinds of questions are asked? Who chooses the learning materials? How is progress evaluated? Who evaluates it? (p. 12). 
Having in mind these considerations, it is important to see how the roles assumed by students and teachers most of the times respond to relations of power. In terms of teacher voice, for example, we can say that we have the authority to assign tasks, to be listened and obeyed, to be respected, and to silence, among others. Silecing students voice is called by Freire (1987) the "lecture format" of teaching (p.44). Based on this approach, the teacher is the only one who talks and students voice disappears. They are supposed just to repeat and memorize. Their experiences and strengths do not count. Thus confirming what Ira Shor asserts "(. . .) the social relations of the classroom are alienating and silencing" (p. 12).

\section{The Inner Voice}

This can be heard in teacher voice when he/she decides to implement a specific curriculum, use special materials, include certain topics, etc. Most of the times, we as teachers do not recognize that these kinds of decisions carry implications. Mostly, we pursue 'our' interests rather that our students' needs and expectations.

At this respect, Freire (1987) and Penny Cook (2001) support this consideration.The first author affirms that everything around teaching and learning process are under the teacher voice. Only his/her beliefs are taken into account. "The selection of materials, the organization of study, the relations of discourse, are all shaped around the teacher's convictions" (p. 33).

Pennyccok (2001) also refers to this fact. He labels it as "cultural preferences".

The language we teach, the materials we use, the way we run our classrooms, the things students do and say, all these can be seen in social and cultural terms, and thus, from a critical perspective as social political and cultural political questions (p. 129).

That is to say that our voice is shaped also by aspects we consider are not so relevant, or maybe we do not think of our choices and preferences in terms of political and ideological decisions.

\section{The Voice of Minorities}

This voice is one from which I am more conscious about. When I "name" minorities, I refer to the Colombian Government and more specifically, to 
the Distrital Government in Bogotá and its policies and mandates. As it has been said above, our schools are microcosms that represent "broader social, cultural, and political relations" (Pennycook, 2001, p. 114). Being so, teacher voice at times is forced to include certain discourses from the minorities. I am going to illustrate this with a real life example: in my school, a project called "Competencias Laborales" has been adopted. Although teachers were not asked about adopting or not the project, the administrators decided to implement it. As a result, nowadays the staff of teachers has had to develop specific steps in order to evidence that we are implementing the project in our settings.

This is just an example of how the Distrital Government in Bogotá oppresses the stakeholders to carry out certain projects. As a result, the stakeholders oppress the teachers to implement them, and the teachers oppress the students to present "successful experiences". There is a quote by a colleague that illustrates this issue. She said: "who is oppressed, becomes oppressor." That is what it is happening. And for doing so, the minorities present (I would say sell) those types of projects under an optimistic perspective. Freire (1987) argues:

Because, for me, the domination by an elite, the exploitation of people by a minority, requires the ruling groups precisely to deny that they are doing it to someone else. They are required to hide it from people who are dominated. Myths and explanations must be invented to hide domination and present it as something else (p. 45).

Further mores, our voice (teacher voice) becomes the channel of minorities. Canagarajah (1993), cited in Pennycook, (2001), considers that our educational settings and classrooms are not autonomous places. He labels their autonomy as relative. "(. . . ) suggesting both that they are social and cultural domains unto themselves and that they are interlinked with the world outside"(p. 117). In addition, Pennycook (2001) relates this fact with the term freedom: "this version of free individuals misses an understanding of how society, culture, and ideology make us anything but free" (p. 119).

To conclude, I want to add that our voice -considering the project cited above and the fact that we are not completely autonomous- becomes one way in which domination and subjugation remain in our society. As Bowles and Gintis (1976), as cited by Pennycook, (2001) conclude: "schools operate to 
reproduce the labor relations necessary for the functioning of capitalism, this focus on the roles of schools in the reproduction of social inequality has been an important focus on critical sociology of education" (p. 121).

\section{Conclusions}

The reflective process I have gone through while reading and thinking about the ways teacher voice is shaped has made me realize of teachers' role as agents of social change. I believe that unless we become aware of this fact and the implications it has for our practices, the school system will remain as the means by which the minorities perpetuate social inequality.

Thus, I conclude that our voice may be shaped by voices outside the school borders like the voice of political relations of power, in which we maintain the pre-existing and unequal social hierarchies. Besides, our inner voice also plays a role in our practices. Unfortunately, we have been said for a long time that the educational process is all in the teachers' shoulders. That might be another fact that shapes our voice as teachers. Finally, being the school a social microcosm, the forces around it are presented in our practices and discourses, as well.

Based on what it could be concluded from this paper, there are a lot of challenges we, as educators could assume. To begin with, the first step is to become conscious. To reflect upon what we are doing, saying and how we are maintaining an unequal system. In words of Wink (2000): "it means that we have voice and the courage to question ourselves and the role we are playing in maintaining educational processes that we do not value" (p. 37). It is time to begin this process.

Besides, we need to become aware of our political role in education. When we realize that we have a responsibility in transforming reality, that we have the power to do it, our voice will begin to become more autonomous. After that, we will be able to assume our political position and choice. As Freire (1987) proclaims: "the teacher works in favor of something and against something" (p. 46). It implies to link what I believe in and the actions I do. In other words, to be consistent.

Lastly, it is important to think of a different approach. To take into account our students' experiences, beliefs, problems, and include them in our teaching plans. As Giroux (1999) points out: 
Teachers should construct curricula that draw upon the cultural resources that students bring with them to the school. This suggests not only taking the languages, histories, experiences, and voices of the students seriously, but also integrating what is taught in schools to the dynamics of everyday life.

Giroux's point of view about the role of teachers in CP coincides with the idea of dialogue format stated by Freire (1987). This type of format implies "a problem-posing illumination which criticizes itself and challenges students' thinking" (Freire, 1987, p. 40). In short, transform classrooms in a piece of theatre, rather than a monologue in which only teacher voice (and all the other voices that shape it) is heard.

\section{References}

Cummins, J. (1989) Empowering mindrity students. In wink, J. Critical pedagogy. New York: Addison Wesley Longman, Inc.

Freire, P. \& Ira Shor. ( 1987). How can Teachers Become Liberating Educators. In P. Freire \& Ira Shor (Eds.), A Pedagogy of Liberation. Dialogues on Transforming Education. (pp. 17-51). Bergin \& Garvey Publishers.

Freire, P. \& Ira Shor. ( 1987). The Dream of Liberating Education. In P. Freire \& Ira Shor (Eds.), A Pedagogy of Liberation. Dialogues on Transforming Education. (pp. 1-15). Bergin \& Garvey Publishers.

McLaren, P. (2002). Teachers and Students. In P. McLaren (Ed.), Life in Schools. An introduction to Critical Pedagogy in the Foundations of Education. (pp. 242-253). L.A.: A and B University of California.

Pennycook, A. (2001). The Politics of Pedagogy. In A. Pennycook (Ed.), Critical Applied Linguistics: A Critical Introduction. (pp.114- 140). New Jersey: Lawrence Erlbaum Associates.

What is Critical Pedagogy? (1999). Retrieved May 17, 2004, from http://www.perfectfit. org/giroux2.html

What is the Role of Teachers in Critical Pedagogy? (1999). Retrieved May 17, 2004, from http://www.perfectfit.org/CT/giroux4.html\#top

Wink, J. (2000). Critical Pedagogy. What in the World Is It? In J. Wink (Ed.), Critical Pedagogy. Notes from the Real World. (pp. 27- 74). New York: Addison Wesley Longman. 


\section{THE AUTHORS}

Claudia Becerra holds a B.A. in Modern Languages from Universidad Distrital and she is currently enrolled in the Masters Program in Applied Linguistics at Universidad Distrital. She is working at Instituto Educativo Distrital IED Naciones Unidas II, Ciudad Bolívar. She has been a teacher for the Secretary of Education in Bogotá since 2000. E-mail: flaquitica@yahoo.com.ar • flaquitica@hotmail.com 